\title{
ON THE MEANING OF ENGLISH IN THE EDUCATION OF FUTURE TEACHERS
}

\author{
CSaidvalieva D., ORCID: 0000-0001-9058-7797, Tashkent University of Information Technologies, \\ Tashkent,Uzbekistan,diafruka@gmail.ru
}

\section{О ЗНАЧЕНИИ АНГЛИЙСКОГО ЯЗЫКА В ОБРАЗОВАНИИ БУДУЩИХ ПЕДАГОГОВ}

\author{
ССаидвалиева Д. P., ORCID: 0000-0001-9058-7797, Ташкентский университет \\ информационных технологий, г. Ташкент, Узбекистан, diafruka@gmail.ru
}

Abstract. In this article, we would like to discuss the role of English as the global language and its impacts on our profession as English teachers. Foreign languages open doors to development and give access to international education. English has roles as both an international and a global language. As an international language, English has played a role as the tool of communication among people from different countries, in other words, English is used to bridge linguistic odd among people in international communities.

Аннотация. В этой статье мы хотели бы обсудить роль английского языка как глобального языка и его влияние на нашу профессию преподавателя английского языка. Иностранные языки открывают двери для развития и дают доступ к международному образованию. Английский язык играет роль как международного, так и глобального языка. В качестве международного языка английский является инструментом общения между людьми из разных стран.

Keywords: English language, international education, technological facilities, computer and Internet technology.

Ключевые слова: английский язык, международное образование, технологическое оснащение, компьютерные и интернет-технологии.

It is well known that our new life is highly affected by the era of information technology, and technology plays an important role in today's human society development. Based on this fact, it is indispensable to take advantage of the modern technological facilities in aiding the task of English language education. Students trying to learn English as a second language need further language support. They need to practice in hearing the language, reading language, speaking language, and writing the language in order to develop their experience and skills. For doing such tasks, they are in need of using various tools which can help them learn the language easily and effectively [1].

The term New Technology includes communication techniques for language teaching in which the personal computer plays a central role. There are, however, other technological tools that can be utilized in language learning besides computers. Each technological tool has its specific benefits and application with one of the four language parts (speaking, listening, reading, and writing). However, in order to use these techniques successfully, the ELL student should be familiar with using computers and the internet, and capable of interacting with these techniques. The effect of technology has become huge in teaching and learning the language in addition to the instructor's role. In other words, the role of the instructor together with the role of the technology can lead to advanced learning results [2]. 
Learning a new language is a challenging task. It demands hundreds of hours of study and dedicated, regular practice. It is also an immensely rewarding experience; learning a new language opens doors to new cultures and even new ways of thinking. Learning English can be a challenging and daunting task. Fortunately, technological advancements have now made learning the English language much more easy, fun, and convenient. One technologically advanced method that has improved the way people learn English is the Internet. This modern form of communication has opened the world to a whole new way of learning the English language. The vast resources on the Web make learning English a less intimidating undertaking [3].

The Internet offers a wealth of information and unlimited resources that teachers can use in order to expose students to authentic language use. Exposure, however, is not enough to trigger language acquisition. Students need to be involved in tasks that integrate the use of computers and enhance language acquisition.

When one embarks on the process of learning English, they require a number of learning materials such as textbooks, videos, and audio tapes. Traditionally, it was difficult to locate all of the appropriate educational materials. It took a lot of time an effort to find the most appropriate learning tools. Now, with a simple click of the mouse, one has a world full of materials that they can access. For instance, sites such as YouTube contain many video lessons on learning to speak English [4].

In recent years, integrating computers and Internet technology in the teaching and learning process changed the way in which instruction was delivered to students. The Internet plays a great role in foreign language teaching and learning. Learners have access to many English language resources if they use computers and the Internet in language classes. They can improve their listening, speaking, reading, and writing skills through a real-world situation. Because of the widespread use of computers and the Internet in educational settings, language teachers are motivated to implement this technology in their classes in order to facilitate language teaching and learning process. Educators are the real representatives of utilizing technologies in language learning [5].

One important factor which influences the use of educational technology in classes is the attitudes of teachers toward integrating the Internet in their language classes. Teachers' attitudes toward technology use can be concerned as a facilitating or hindering factor, which gives them more comfort or obstacle to utilizing technology in their educational environments. Computers and Internet technology are the most effective tools among various existing technological aids in teaching and learning languages. Integrating and applying computers and the Internet in a learning environment can strengthen the way that students acquire a foreign language effectively. Hence, teachers' attitudes play a fundamental role in the real utilization of technologies in classrooms.

Using the Internet can facilitate the development of language skills, employability skills, and critical literacy.

Language skills:

-Skimming and scanning;

-Reading narratives, charts, and graphs;

-Accessing ESOL and life skills content sites;

-Writing: completing forms, emailing requesting information.

Employability skills:

-Analyzing and evaluating information;

-Decision making;

-Problem-solving;

-Technology skills [6]. 
Learning the English language will improve job opportunities and open up the doors to career advancement. Because the Internet has become a big part of most people's lives, the wealth of information posted from all over the world makes it a valuable tool when learning to speak and write the English language.

Computers and the Internet are a great resource for classroom teachers! Teachers can find suggestions, lesson plans, practical support, information, and materials through the Internet. In fact, using a computer can make a teacher's life easier and more efficient. The leaders' website provides an extensive list of Internet links designed to help teachers of reading and writing. This list of links covers most of the types of websites discussed below. Here are some of the many ways in which teachers can make computer and Internet technology work for them.

One particularly practical feature of many of the new teacher websites currently available on the Internet is the provision of ready-made lesson plans and suggested activities on a broad array of topics. When teachers become aware of how to find information online, they can help their students begin to tap into this huge resource. This skill is useful to students not only for accomplishing their homework but also as a survival skill in the modern workplace. In addition, there are some websites that offer online help from teachers for students who need assistance with their homework.

Teachers should make sure they investigate the quality of this homework help before recommending a website. There are many online resources specifically tailored to the needs of parents. Teachers who are aware of these resources can recommend useful websites to the parents of their students. So, the Internet is an exciting resource for teachers. Using the Internet can make teachers' lives simpler and can provide more information and resources than ever available before. The Internet is a way for students and teachers to learn and to connect with others. Last but not least, the Internet can be just plain fun for students and teachers alike [7].

The implementation of Internet resources in the context of EFL classes as research study concludes that the integration of web-based activities and tools are useful for language teachers and learners who are disposed to incorporate these resources in their EFL classes. To sum up, the internet was seen as an important support during the study to foster learners' autonomy and motivation, instead of providing teachers and students with resources that allow them to have a significant language learning and teaching process, as the web exposes users to an amount of information which is helpful, interesting and adaptable as well as for English learning or teaching purposes. It was also found that despite the fact that the web supplies students with information and valuable sources, the teacher's monitoring is in the students' thinking for rising up their confidence to perform with the target language since the facilitator helps with clarifications and support to those reluctant students and those who lacked the technological abilities needed during the interaction with the exercises on the web [8].

As it is well known, the World Wide Web is appealing for the learners, which became a great advantage for teachers in the study, who incorporated web resources in the context of EFL classes, to maintain students' positive attitude and engage them towards the process of language learning. In addition, it was evidenced that even though students were willing to learn and practice the language using web resources as it has been mentioned before, they had gaps and insecurity when they were exposed to the development of the web-based activities, this is why students and researchers have highlighted through observation and interviews, the importance of basic computer management skills for a successful accomplishment and creation of exercises through web tools [9]. 
Teaching for Success uses high-quality continuing professional development opportunities to help teachers and teacher educators improve their performance and achieve better results from their learners.

\section{References:}

1. Albirini, A. (2016). Teachers' attitudes toward information and communication technologies: The case of Syrian EFL teachers. Computers and Education, 373-398.

2. Kim, H. (2015). Teachers as a barrier to technology-integrated language teaching. English Teaching, 57(2), 35-64.

3. Rost, M. (2014). New technologies in language education: Opportunities for professional growth. Retrieved from http://www.longman.com/pdf.

4. Bolam, R. (2000). Emerging policy trends: some implications for continuing professional development. Journal of In-Service Education, 26(2). 267-280. https://doi.org/10.1080/13674580000200113.

5. Dymock, D., \& Tyler, M. (2018). Towards a more systematic approach to continuing professional development in vocational education and training. Studies in Continuing Education, 40(2), 198-211. https://doi.org/10.1080/0158037X.2018.1449102

6. Mardapi, D. et al. (2018). Assessing teacher competence and its follow-up to support professional development sustainability. Journal of Teacher Education for Sustainability, 20(1), 106-123. https://doi.org/10.2478/jtes-2018-0007.

7. Hubbard, P. (2018). Technology and professional development. The TESOL Encyclopedia of English Language Teaching, 1-6. https://doi.org/10.1002/9781118784235.eelt0426.

8. Misra, P. (2018). MOOCs for teacher professional development: reflections and suggested actions. Open Praxis, 10(1), 67-77. https://doi.org/10.5944/openpraxis.10.1.780.

9. Kessler, G. (2006). Assessing CALL teacher training: What are we doing and what could we do better? In: P. Hubbard \& M. Levy (Eds.), Teacher education in CALL. Amsterdam, Netherlands: John Benjamins. 23-42. https://doi.org/10.1075/11lt.14.05kes.

\section{Список литературы:}

1. Albirini A. Teachers' attitudes toward information and communication technologies // The case of Syrian EFL teachers. Computers and Education, 2016. 373-398 p.

2. Kim H. Teachers as a barrier to technology-integrated language teaching // English Teaching. 2015. V. 57. №2. P. 35-64.

3. Rost M. New technologies in language education: Opportunities for professional growth. (2014). Retrieved from http://www.longman.com/pdf.

4. Bolam R. Emerging policy trends: some implications for continuing professional development // Journal of In-Service Education. 2000. V. 26. №2. P. 267-280. https://doi.org/10.1080/13674580000200113

5. Dymock D., Tyler M. Towards a more systematic approach to continuing professional development in vocational education and training // Studies in Continuing Education. 2018. V. 40. № 2. P. 198-211. https://doi.org/10.1080/0158037X.2018.1449102.

6. Mardapi D., Herawan T. Assessing teacher competence and its follow-up to support professional development sustainability // Journal of Teacher Education for Sustainability. 2018. V. 20. №1. P. 106-123. https://doi.org/10.2478/jtes-2018-0007.

7. Hubbard P. Technology and professional development // The TESOL Encyclopedia of English Language Teaching. 2018. P. 1-6. https://doi.org/10.1002/9781118784235.eelt0426. 
8. Misra P. MOOCs for teacher professional development: reflections and suggested actions. // Open Praxis. 2018. V. 10. №1. P. 67-77. https://doi.org/10.5944/openpraxis.10.1.780.

9. Kessler G. Assessing CALL teacher training: What are we doing and what could we do better? // P. Hubbard \& M. Levy (Eds.), Teacher education in CALL 2006. P. 23-42. Amsterdam: John Benjamins. https://doi.org/10.1075/11lt.14.05kes.

Работа поступила

в редакиию 10.03.2019 2.
Принята к публикациии

14.03.2019 2.

Cite as (APA):

Saidvalieva, D. (2019). On the Meaning of English in the Education of Future Teachers. Bulletin of Science and Practice, 5(4), 452-456. https://doi.org/10.33619/2414-2948/41/66.

Ссылка для иитирования:

Saidvalieva D. On the Meaning of English in the Education of Future Teachers // Бюллетень науки и практики. 2019. Т. 5. №4. С. 452-456. https://doi.org/10.33619/2414-2948/41/66. 